UDC 340.6: 378.147

DOI https://doi.org/10.32836/2521-6473.2021-4.7

\author{
Yu. V. Lomzhets, Candidate of Political Sciences, \\ $\mathrm{PhD}$, Associate Professor, Head of the Department of Maritime and \\ Commercial Law Admiral Makarov National University of Shipbuilding
}

\title{
STRENGTHENING THE ROLE OF LEGAL CLINICS AS A BASIS FOR PRACTICAL TRAINING OF WORKERS IN THE CONTEXT OF LEGAL EDUCATION REFORM
}

The article is devoted to the analysis of the current state of development of the institute of legal clinics in Ukraine, the study focuses on its historical aspects, it is noted that in 2021 the Ukrainian clinical movement is fulfilled 25 years old, as one of the criteria of periodization the dynamics of legal (normative) regulation of activity of legal clinics is analyzed. There are five main stages in the formation of the clinical movement in Ukraine. Special attention is paid to the analysis of features of activity and prospects of development of legal clinics in the conditions of modern reforming of system of education in Ukraine, further institutionalization of legal clinics as an integral component of legal education. The state of development of legal clinics in recent years under the influence of such factors as: European integration processes, informatization of society, change of formats of activity in the conditions of pandemic of 2020-2021 is estimated. Focused on the role and importance in the system of clinical movement of the Association of Legal Clinics of Ukraine, it is concluded that it is the Association that applies the vector of development of the entire system. There is an increase in the level (according to different criteria) of legal clinics in Ukraine due to the popularization of the movement itself, its gradual institutionalization, improvement of monitoring systems with the provision of expert assistance and the like.

The practical aspects of the activity of legal clinics during 2020-2021 are analyzed on the example of the legal clinic "Exaequoetbono" of the National University of Shipbuilding named after Admiral Makarov. Fruitful participation in AllUkrainian and international events organized on the initiative of the Association of Legal Clinics of Ukraine is noted.

As a result of the study, conclusions were made about the current state of development of legal clinics in Ukraine as a well-established institution, with a legal framework (which still requires some changes), forms and methods of activity, a clear practical orientation in the training of specialists in law. This gives grounds to say that we have excellent prospects for the development of the legal clinical movement, especially in the context of gradual integration into the European community, within the course chosen by Ukraine in 2014 and adequate funding.

Further development of separate directions of activity of legal clinics with use of information and communication technologies (on-line, off-line) is forecasted. The most effective is the use of such forms for legal education and legal assistance.

Key words: Legal clinic, Association of Legal Clinics of Ukraine, legal assistance, legal education.

Ю. В. Ломжець. Посилення ролі юридичних клінік як бази практичної підготовки працівників у контексті реформи юридичної освіти

Статтю присвячено аналізу сучасного стану розвитку інституту юридичних клінік в Украӥни, у рамках дослідження сконцентровано увагу на його історичних аспектах. Відзначено, щчо в 2021 р. украӥнському клінічному руху виповнюється 25 років, як один із критеріїв періодизачії проаналізовано динаміку правового (нормативного) врегулювання діяльності юридичних клінік. Виокремлено п'ять основних етапів у становленні клінічного руху в Україні. Окрему увагу присвячено аналізу особливостей діяльності та перспектив розвитку юридичних клінік в умовах сучасного реформування системи освіти в Україні, подальшій інституціалізації юридичних клінік як невід'ємної складової частини юридичної освіти. Очінено стан розвитку юридичних клінік в останні роки під впливом таких чинників, як євроінтеграційні процеси, інформатизація суспільства, зміна форматів діяльності в умовах пандемії 2020-2021 рр. 3осереджено увагу на ролі та значенні у системі клінічного руху Асочіації юридичних клінік України, зроблено висновок про те, щцо саме Асоиіачія завдає вектор розвитку всієї системи. Відзначено підвищення рівня (за різними критеріями) юридичних клінік України завдяки популяризації самого руху, його поступової інституціалізації, поліпшення систем моніторингу з наданням експертної допомоги тощо.

Проаналізовано практичні аспекти діяльності юридичних клінік протягом 2020-2021 рр. на прикладі юридичної клініки Ехаеqиоеtbono Національного університету кораблебудування імені адмірала Макарова. Відзначено плідну участь у всеукраїнських та міжнародних заходах, організованих за ініціативою Асоціації юридичних клінік України.

У результаті проведеного дослідження зроблено висновки про сучасний стан розвитку юридичних клінік в України як иілком сформований інститут зі сформованою правовою основою (яка все ж потребує певних змін), формами та методами діяльності, чіткою практичною спрямованістю у системі підготовки фахівиів у галузі права. Це дає підстави стверджувати, щсо ми маємо чудові перспективи розвитку юридичного клінічного руху, особливо за умов поступової інтеграції до європейського співтовариства, у рамках вибраного Україною курсу в 2014 р. та належного фінансування.

Спрогнозовано подальший розвиток окремих напрямів діяльності юридичних клінік із використанням інформаціийно-комунікаційних технологій (он-лайн, офф-лайн). Найбільш ефективне застосування таких форм для правопросвітніцької діяльності та надання правової допомоги.

Ключові слова: юридична клініка, Асоціаџія юридичних клінік Украӥни, правова допомога, правова просвіта.

(C) Yu. V. Lomzhets, 2021 


\section{Formulation of the problem.}

Traditionally for many sciences, including legal, the modern stage of development of Ukraine is associated with the acquisition of independence. For 30 years of independence, systemic changes have taken place in all spheres of the life of Ukrainian society. Against the background of these reform processes, the legal education system is also experiencing. Now we must admit that the excessive enthusiasm in the late 1990 s and early 2000 s in this particular area of knowledge attracted a large number of educational institutions of different levels to licensing, sometimes without a proper base and teaching potential, and led to the opposite process - a decline in the quality of specialists. These and many other problems we face require positive changes to improve the level of legal education and the quality of specialists. One of the "short stories" in the development process for educational institutions, in our opinion, is the institute of legal clinics, which were started as an element of the practical training of a legal specialist and now constitute an element of licensing requirements.

Considering the specifics and role of legal clinics in the process of training lawyers, this issue has received a lot of attention from the scientific community.

Among some of the first comprehensive domestic works devoted to the issues of legal clinic, one should single out such authors as: A.A. Galai. [1], Goncharenko V.A. [2], Elov V. [3], Katsavets G.S., Moldovan V.V. [4], Stadnik V.V. [1], etc.

The works of Galay A.A. deserve attention [5], which in the context of the dissertation research (section IV) and a number of its articles reveals the features of the work of legal clinics. At the level of dissertation research we can also note the work of M.T. Lodzhuk.

Thus, we have a sufficiently formed institute, which is a necessary component in the training of a legal specialist, however, it requires further attention from the scientific community and lawyers.

The aim of the work is to analyze the features of the activities and prospects for the development of legal clinics in the context of the modern reform of the education system in Ukraine.

The subject of the research is the legal clinic itself, which has become an integral part of legal education.

The object of the research is the social relations developing within the framework of the institution of legal clinics

Main part.

The history of the development of the legal clinical movement in the world is more than a century. The domestic idea of legal clinics, in which law students provide free legal advice to ordinary people, arose in the middle of the 19th century in Russian Kazan. Several other universities have used this experience, including the Kiev University of St. Vladimir.

The first legal clinics in independent Ukraine began to appear during 1996-1999 with the direct participation of youth, student and other public organizations (in the cities of Kiev, Donetsk, Lvov, Odessa, Lutsk, etc.). In the 2000s began a further development of this element of educational and human rights nature [3, p. 7]. We are talking not only about legal clinics formed on the basis of educational institutions, but also about public organizations formed in the framework of human rights activities, among which the Ukrainian Helsinki Union, Kharkiv Human Rights Group and the like should be highlighted. The commonality of the latter two is explained by the general concept of clinical movement, as well as participation in joint activities of the scientific and practical direction.

One of the researchers of the problems of legal clinics, Lodzhuk M.T., distinguishes four stages in the history of their development [5, p. 5]: 1) the local level of legal regulation as public organizations or in their structure (1996-1999); 2) the local level of legal regulation in the structure of higher educational institutions as a source of legal information for the population (1999-2002); 3) the local level of legal regulation in the structure of higher educational institutions as a component of the educational institution or educational process (2002 - August 2006); 4 ) the subordinate regulatory level of legal regulation as the basis for the practical training of law students (from June 2006 to the present time).

That classification as a whole does not differ from those proposed earlier, however, in our opinion, it is advisable to add at least one more - the fifth stage 2014-2021, with a possible division into sub-periods.

A significant success in this process was the formation of the Association of Legal Clinics of Ukraine since 2005. For 16 years of its activity, the Association has united a significant number of scientific and student communities. Today it brought together more than 70 law clinics in many regions of Ukraine. The works in the formation of the regulatory framework should be noted, embodying it in the standard ah development of legal clinics, the Model provisions on the legal clinic, the Code of Ethics of legal clinics in Ukraine. For the first time such a standard was approved by the Congress of the Association in 2003. The current edition of the Standards for the activity of legal clinics in Ukraine was approved by the All-Ukrainian Congress of the Association of Legal Clinics of Ukraine Protocol No. 2 dated June 19, 2014 [7]. The provisions of these documents have become a kind of development vector for legal education, an increase in the level of practical training is a prerequisite for the formation of a quality specialist. So, the current Standards provide for the implementation of six key areas in the activities of legal clinics in Ukraine, including: unification of the structure, emphasis on the practical training of students (cadets), which is organically connected with the educational process, the formation of a system of free legal aid and legal education. 
It is advisable to analyze the features of the organization and activities of legal clinics and the prospects for their development using the example of individual legal clinics. Thus, the southern regions of Ukraine (Nikolaev, Odessa, Kropyvnytskyi, Zaporozhye region) unite more than 12 clinics. Nikolaev region is represented by legal clinics, which are based on two educational institutions:

1. Legal clinic "Exaequoetbono» of the National University of Shipbuilding named after Admiral Makarov.

2. Legal Clinic "Veritas" of the Black Sea National University named after Peter Mogila.

We can use the example of the first to reveal certain aspects of the activities of legal clinics. Legal clinic "Exaequoetbono» of the National University of Shipbuilding named after Admiral Makarov was established in 2000 at the Department of law (now - Faculty of Maritime Law). With a long time of its operation more than one thousand students had the opportunity to acquire practical skills in the legal profession. For many students, the experience of working in a legal clinic has not only a professional component, but also an emotional one. Since the exchange of experience that occurs within the framework of solving specific cases for clinical students forms rather close ties between its participants. The practice is not alone when recent graduates, especially active participants in this movement, choose the educational path in the future and continue to participate in the work of the clinic as curators.

Within the framework of the institute of a legal clinic, a system of norms operates, which differ in their classification characteristics (legal force, subject of publication, validity period, etc.), since it is guided by the legislation of Ukraine on higher education, the Model Regulations on the Legal Clinic of a Higher Educational Institution of Ukraine, approved by the Ministry of education and science of Ukraine from 03.08.2006 number 592 [8], the Charter of the University, the provisions of the law clinic and other regulations, governing the organization of the work of legal clinics in the institutions of higher education and the provision of legal aid.

That gives the ground to talk about the formation of a complex institute, which over the past 20 years has become an important component of the training of lawyers.

An important direction is the question of introducing special courses on organizing the work of legal clinics and passing internships on their basis. The legal basis for such courses is the aforementioned normative documents, but in addition, the Licensing requirements for higher education institutions that train specialists in Faculty 081 Law provide for the introduction of the latter as a discipline of the student's choice. The Association of Legal Clinics of Ukraine has designated and defined a typical thematic plan for a special training course "Fundamentals of Legal Clinical Practice», which became an additional basis for its development and standardization for most of the HEIs in Ukraine. So, at the National University of Shipbuilding named after Admiral Makarov, the study of this discipline by 1st year students is envisaged. Similar programs can be cited as an example at the Ukrainian Catholic University, the National University "Kiev-Mohyla Academy» and others [6].

Analyzing certain aspects of the activities of legal clinics, one cannot bypass the question of their staffing. For a long time, in many educational institutions such activities were carried out on a voluntary basis, and in some institutions of higher education and on a similar line of activity, do not provide for a separate staff unit - that is, a person who organized the work of the clinic on a professional basis. Taking into account the indicators and experience of the clinics in previous years, most of its participants agree with the thesis about attracting a specialist (s) to the clinic's work on a regular basis, since the need to provide a number of areas, including such components as:

- provision of primary legal aid;

- participation in the legal process about the worlds of citizens;

- scientific and practical events (round tables, seminars, congresses, olympiads, etc).

That issue, which is within the competence of the management of the educational institution and the staffing table, is approved by the order of the rector.

Particularly positive is the participation of practicing lawyers in the work of a legal clinic, it is useful for them to attract lawyers to work in the clinic, and it allows them to better work out the sphere of procedural law.

Ukrainian scientist A.A. Galai focused on that issue, allocating the system elements of quality management in the activities of the staff of legal clinics (planning and carrying out its tasks the formation and development of personnel, evaluation of the results of the legal clinic activities in conjunction with other similar institutions of the developed methodology which includes 30 criteria) [5, p. 19].

In principle, the implemented initiative on the proper rationing of the workload, rationing of the accounting of educational work of teachers in legal clinics, however, its implementation often comes into contact with insufficient funding, the number of students who chose this profession is also not of last importance.

The staff of the Legal Clinic may include: the head of the Legal Clinic, tutors, coordinators and others, with the formation of their job descriptions. Teachers-curators who are scientific and pedagogical workers of specialized departments and have experience in practical legal activity can also be involved in the work of a legal clinic. Such activities can be the basis for the allocation of appropriate time in their work schedule and study load. However, these norms are of a dispositive nature and, as a rule, are solved within the competence of the educational institution.

In recent years, there have been positive changes in the development of legal clinics in Ukraine, as evidenced by the constant increase in the number and quality of clinics, so in 2016 the Association included 56 clinics, and in 2020 there are already 62 , the volume and format of events also indicates an increase in the level of this institute. 
Although the 2020-2021 pandemic is making its own adjustments to the activities of all spheres of life, however, for the provision of legal assistance and legal education, preconditions have been created for the wider use of information and communication technologies, through various online events, this has become a trend in 2020-2021 years. Therefore, especially law activity is gradually transformed in the conditions of the information society, forming on its pages of law content, conducting on-line seminars, lectures, conversations and the like.

In 2019-2020, at the initiative of the Association of Legal Clinics of Ukraine, a number of innovations were introduced [9]:

1) improved monitoring of the level, entering the expert support ;

2) implemented new models of student counseling competitions, the transfer of internal competitions exclusively in English;

3) deepening regional cooperation through the implementation of joint projects in the field of mediation, support for small businesses;

4) an independent project activity has begun. So, in 2019, the project "Development of Regional Leadership and Strengthening the Coordination Model of the Association of Legal Clinics of Ukraine» from the International Renaissance Foundation received support [9].

In addition, the Association has become a platform for international internships and professional development of lecturers-curators of legal clinics (in June 2019 based at the University of Warsaw, Poland).

Thus, while analyzing the information posted on the website of the Association of Legal Clinics of Ukraine, we can come to separate conclusions:

1. Law clinical movement being actively developed as an integral component of the training of lawyers;

2. The number of appeals taken into account when providing statistical data, annually in Ukraine totals more than ten thousand, even in the conditions of a pandemic in 2020, more than eight thousand were considered;

3. Since 2004, the Association has been forming the normative and methodological basis of the legal clinical movement in Ukraine, the typical thematic plan of the special training course "Fundamentals of Legal Clinical Practice» has been determined, the main result of these processes is the standardization of the legal clinical movement and the forecasting of innovations;

4. During 2014-2021, there have been cardinal changes in the direction of European integration, the formation of a competitive specialist on a par with the world's leading models, approaches to understanding the role of legal clinics and the vectors of its development have been revised.

Despite the fact that the goal of state reforms in the field of education is to train a competitive, high-quality specialist, taking into account modern realities and the needs of society, there are a number of problems that, to one degree or another, affect the institution of a legal clinic:

1. One of the traditional problem is financing the activities of a legal clinic and the region as a whole. As a rule, the maintenance of a legal clinic is entrusted to the educational institution, as a subject, must fulfill the licensing requirements. The model regulation on legal clinics since 2006, clause 7 provides for financing of a legal clinic at the expense of higher educational institutions, grants from international and Ukrainian organizations, charitable contributions from citizens and organizations and other sources not prohibited by the current legislation of Ukraine [10]. In modern conditions, one of the possible options for alternative financing is project activity and the attraction of grant funds, as a means of supporting the activities of various civil institutions, has gained significant popularity with simplified procedures for such assistance, however, for Ukrainian realities, this is rather poorly regulated by the norms of related branches of law (financial, tax etc);

2. As a result of the appearance in the $90 \mathrm{~s}$ - early 2000 s, a significant number of educational institutions of various forms of ownership, training students in the legal specialty, some of which, for various reasons, do not withstand competition - this, in turn, leads to a decrease in the quality of specialist training. Regarding the activities of legal clinics in such educational institutions, the matter is exclusively voluntary, and as a rule does not even imply an hour in the teacher's workload, as provided by the regulations. It is the legal clinics of those educational institutions that have a small licensed enrollment of students that need maximum monitoring, since in these conditions, hours for such work are often not included in the workload of curators, and clinics often work purely formally, increasing the amount of paperwork of teachers without real results of work.

However, in 2014 it became a defining year in the modern history of Ukraine; from this year that the modern stage of its development begins. Not the least role in this was played by the hybrid war of the Russian Federation against Ukraine, acting as a kind of catalyst for internal processes in our state. Regarding the subject of our research, we can highlight several key points for the institute of legal clinics:

- improving the regulatory framework of this movement, a special role in this belongs to the Association of Legal Clinics of Ukraine;

- the course towards European integration and the Association Agreement with the EU 2014 created the preconditions for expanding international relations of Ukraine, increasing the representation of our legal clinics at international events of various levels;

- increased attention on the part of the state to the organization and activities of clinics, improving the quality of monitoring of their activities; 
- in the context of a pandemic (COVID-19), the development of information technologies and their implementation in the activities of legal clinics were stimulated.

So, the student and the National of University in Shipbuilding named after Admiral Makarov during the 2020-2021 provided more than 50 legal consultations, held about 30 different law events (online and offline), took part in international student internship "The UP" and Practical Festivals of Law "Street Law" 2021. It is the last event that took place on July 16-17 in Lviv on the basis of the Ukrainian Catholic University - the second annual Street Law Festival. The theme of the competition is "Financial literacy and protection of the rights of consumers of financial services». Such measures w are very important for clinical Ukrainian movement, since the introduction of modern formats provide their conducting pronounced practical directions. According to the chairman of the Association of Legal Clinics of Ukraine Yulia Lomzhets, this is a unique Festival, because there are no analogues of this in the world [11].

\section{Conclusions.}

1. Ukrainian Law Clinical Movement in 2021 celebrates 25 years - a whole generation of Ukrainian lawyers had an opportunity to acquire professional competencies by participating in the work of the clinic.

2. The formation of the legal clinical movement in Ukraine can be divided into five main stages, using several approaches and criteria, including the chronological method, the degree of legal (normative) regulation of the institution, and the like.

3. Associations and legal clinics of Ukraine plays an important system-forming function in this movement, in addition, it acts as a vector for the development of the entire system.

4. Requires a proper regulatory settlement of the issue of securing legal clinics with proper funding, staffing, and expansion of initiatives within the framework of Ukraine's European integration.

5. Ukraine has excellent prospects for the development of the legal clinical movement, especially in the context of gradual integration into the European community, within the framework of the course chosen by Ukraine in 2014.

\section{References:}

1. Галай А.О., Стаднік В.В. Організаційна та управлінська модель юридичної клініки в Україні: забезпечення якісного функціонування : навчальний посібник. Київ : Атіка, 2005. 280 с.

2. Гончаренко В.О. Юридична клініка: історія і визначення. Практика діяльності «юридичних клінік» України. 2004. № 1. С. 3-5.

3. Слов В. Актуальні питання нормативного забезпечення «юридичних клінік» України. Відкритий світ. 2004. № 1.

4. Молдован В.В., Кацавець Р.С. Юридична клініка : навчальний посібник. Київ : Центр учбової літератури, 2007. С. 7.

5. Галай А.О. Адміністративно-правові засади діяльності громадських об’єднань юридичного спрямування в Україні : автореф. дис. ... д.ю.н. : 12.00 .07 ; Національна академія прокуратури України. Київ, $2015.38 \mathrm{c}$.

6. Лоджук М.Т. Правове регулювання діяльності юридичних клінік в Україні: загальнотеоретичне дослідження : автореф. дис. ... к.ю.н: 12.00.01 ; Нац. ун.-т «Одеська юридична академія». Одеса, 2014.22 с.

7. Стандарт діяльності юридичних клінік в Україні : Рішення Всеукраїнського з'їзду Асоціації юридичних клінік України. Протокол № 2 від 19 червня 2014 p. URL: https://legalclinics.in.ua/wp-content/ uploads/2017/07/standarti-diyalnosti-yuridichnikh-klinik-ukrajini.pdf.

8. Про затвердження Типового положення про юридичну клініку вищого навчального закладу України : Наказ МОН України від 03.08.2006 № 592. URL: https://zakon.rada.gov.ua/laws/show/z0956-06\#Text.

9. Основи юридичної клінічної практики: комплекс навчально-методичного забезпечення навчальної дисципліни : навчальний посібник / уклад. А.М. Бежевець. Київ : КПІ ім. Ігоря Сікорського, 2017.37 с.

10. Офіційний вебсайт Асоціації юридичних клінік України. URL: https://legalclinics.in.ua/pro-nas/dosy agnennya/\#1588500155539-3db7265b-8987.

11. «Пофестивалили у Львові»: підсумки унікального Фестивалю з практичного права. Офіuійинй вебсайт Асоціації юридичних клінік України. URL: https://legalclinics.in.ua/pofestyvalyly-u-lvovi-pidsumkyunikalnogo-festyvalyu-z-praktychnogo-prava/. 